\title{
Names, Light Nouns, and Countability
}

\section{Friederike Moltmann}

Making use of Kayne's (2005, 2010) theory of light nouns, this article argues that light nouns are part of (simple) names and that a mass/ count distinction among light nouns explains the behavior of certain types of names in German as mass rather than count. The article elaborates the role of light nouns with new generalizations regarding their linguistic behavior in quantificational and pronominal NPs, their selection of relative pronouns in German, and a general difference in the support of plural anaphora between English and German.

Keywords: names, proper names, light nouns, special quantifiers, mass/ count distinction, location, predicativism

It is a standard assumption that proper names for entities of different types have the very same semantics, denoting well-individuated entities and thus classifying as count nouns. It has moreover become a standard view in philosophy of language that names are rigid designators standing for the same entities in different circumstances in virtue of the causal-historical chain to which they belong on a given use. A less standard view, argued for by philosophers such as Geach (1957) and Dummett (1973), is that names involve a sortal, as a requirement for a speaker to be able to use them to refer to an entity. This article presents syntactic evidence from German for the presence of sortals in names and argues that different types of names may involve sortals of different kinds and in different ways.

One manifestation of that presence is a surprising division into mass and count among names in German. Names for places as well as what I will call productive names for times, numbers, and expression types in German display diagnostics for mass rather than count status. Making use of Kayne's $(2005,2010)$ silent-noun theory, the article will argue that this is due to the silent presence of mass light nouns in such names - in particular, THING, PLACE, and TIME. THING, PLACE, and TIME also behave as mass nouns when they are overt or silent parts of light quantificational or pronominal NPs in German or English - for example, everything or its German counterpart alles. By contrast, the light noun PERSON classifies as count, being a silent part of names for people and an overt or silent part of light quantificational or pronominal NPs such as everybody (or German jeder) and many. The classification of German names as count when they contain the silent noun HOUSE further supports a mass/count distinction among light nouns.

Names for people and places as well as productive names for times, numbers, and expression types_type 1 names (as I will call them) —are to be distinguished from type 2 names such as

I would like to thank Guglielmo Cinque, Richard Kayne, Gary Ostertag, as well as two anonymous reviewers for comments on a previous version of this article. A precedent of this article was presented at the CUNY Graduate Center and the University of Tübingen, where it greatly benefited from the feedback of the audiences.

Linguistic Inquiry, Early Access Corrected Proof

$1-30$

(C) 2021 by the Massachusetts Institute of Technology

https://doi.org/10.1162/ling_a_00437 
the Hudson River or the Parthenon. Type 2 names, which in German include names for mountains, lakes, temples, and famous precious stones, do not involve a light noun. Rather, they come with a more specific overt or silent sortal and the definite determiner and as a consequence classify as count.

In addition to arguing for the involvement of light nouns in names, the article will present new syntactic and semantic generalizations about light quantifiers such as something and everything, which play a significant role in philosophically relevant contexts.

The article will first establish a number of generalizations about light nouns as part of quantificational and pronominal NPs in English and German. It will then present the empirical generalizations about German type 1 names that point to a mass/count distinction among light nouns and, more briefly, discuss the role of sortals in type 2 names. Finally, it will review a potential alternative explanation for the mass behavior of the relevant German names - specifically, the predicativist theory of names, on which names as common nouns could divide into mass and count.

\section{Light Nouns and Light Quantifiers}

This section will present a number of syntactic and semantic generalizations about light nouns, regarding their characteristic syntactic properties; the ability of the light noun THING to stand for absolutely everything, mass or count; and the selection of different light nouns by different quantifiers or determiners in English and German.

Light nouns play a particular role in certain types of quantificational NPs and pronouns. In English, these include everybody, everything, someplace, and sometime. Here-body, -thing, -place, and -time are light nouns, overt versions of the light nouns PERSON, THING, PLACE, and TIME (Kayne 2005). ${ }^{1}$ Where in everywhere may seem like a light version of PLACE as well; however, following Kayne (2010:chap. 5), where is better regarded as a determiner combining with the silent noun PLACE or THING (more on that later). In English, "bare" occurrences of little, much, more, and a lot as well as the pronoun that contain silent THING. ${ }^{2}$ There are also quantifiers that select PERSON rather than THING-for example, bare occurrences of many and few, on a nonanaphoric use, as in Many / Few believe in God. Quantifiers and pronouns thus may (or may not) select particular overt or silent light nouns. In some languages, light nouns never appear overtly in light quantifiers. This is the case in German (jeder 'everybody', alles 'everything', nichts 'nothing'). Everybody, everything, someplace, sometime, little, and much thus can be called light quantifiers.

Light nouns form a special class of nouns in that they belong to the functional rather than the lexical part of grammar. As such, they have various special syntactic properties. Most importantly, light nouns can stay silent in the absence of an antecedent (Kayne 2005). By contrast, full

\footnotetext{
${ }^{1}$ Everyone, no one, and someone involve a numeral one, again not a noun. Note, however, that one in that context appears to carry the feature [+human], which suggests that one has come to act as a realization of the light noun PERSON.

${ }^{2}$ For some reason, a little bit does not easily take silent restrictions. *John said a little bit is quite bad (as opposed to John said only little). However, John ate a little bit is fine.
} 
NPs can be silent only through "deletion under identity," that is, in the presence of a linguistic antecedent or possibly a salient object in the discourse context. The difference between light NPs and full NPs in that respect can be illustrated by the different readings of many and too much in Many believe in God, John bought many, and John bought too much, which differ in the kind of silent nouns they contain, as in (1).

(1) a. Many PERSON believe in God.

b. John bought many $\mathrm{N}$.

c. John bought too much THING.

Many in (1a), which involves the light noun PERSON, ranges over human beings in general, not requiring an antecedent. Many in (1b), by contrast, requires an antecedent in the preceding discourse (e.g., in the question Did John buy any books?) and thus involves a deleted full noun. Too much in (1c) does not require an antecedent and involves the light noun THING.

In addition to not requiring an antecedent, NPs headed by light nouns (light NPs (DPs)) tend to display different syntactic movement behavior, often having to move to a higher (specifier) position, when full NPs can stay in place (Kayne 2005, Collins 2007). Finally, light nouns do not display the syntactic features of full nouns; in particular, they lack gender features (see below) and show a peculiar behavior with respect to number. Yet, as we will see, they display the mass/ count distinction. ${ }^{3}$ Semantically, the functional status of light nouns means that their range and content should not vary across languages, but rather is part of a universal inventory, constituting the core of grammar.

Light nouns may come with homophonic full nouns. Though there are generally semantic and perhaps historic connections between the two, the light noun and the corresponding full noun need not share their meaning or even their syntactic features. Thus, the light noun -body, an instance of the light noun PERSON, contrasts with the full noun body. The difference between light nouns and homophonic full nouns is particularly striking with the nouns -thing, the overt version of the light noun THING, and thing, the full noun. The light noun -thing permits only postnominal adjectival modifiers, but not so the full noun thing. ${ }^{4}$

(2) a. something nice

b. some nice thing

There are various semantic differences between the full noun thing and the light noun -thing. Thing is a count noun, which applies to an entity by way of contextually given individuation conditions (which is why it is often called a "dummy sortal"; see Griffith 1977). Thing applies

\footnotetext{
${ }^{3}$ On one view, the mass/count distinction consists of a distinction in functional projection, the presence or absence of a classifier (Borer 2005). This view would be untenable if light nouns display a mass/count distinction yet are unable to participate in functional projections (Collins 2007). On the more standard view, nouns are specified as mass or count in the lexicon.

${ }^{4}$ It has been argued that -thing in (1a) has moved to a higher syntactic position, leaving a prenominal adjective in place (Kishimoto 2000). See, however, Larson and Marušič 2004 for arguments that the adjective is in fact in postnominal position.
} 
only to inanimate enduring objects - in fact, usually material objects. The light noun -thing applies to individuals as well as stuff, and thus seems to act as both a count noun and a mass noun (I will return to that in section 4$).^{5}$

(3) a. John ate something, an apple.

b. John ate something, brown rice.

c. John drank something, lemonade.

(4) a. Mary bought something nice, bath salts / chocolate / an art book.

b. Mary bought a nice thing, an art book / *bath salts / * chocolate. $^{6}$

Furthermore, -thing applies to abstract objects of all sorts and not just material entities.

(5) a. John admired something about the stone, its color.

b. John admires something particularly, namely courage.

(6) a. John added two to eight, so he added something to eight.

b. Rouge means something, namely 'red'.

The light quantifier something can even range over pluralities, thus acting as a genuine plural quantifier, which means a (syntactically) singular quantifier ranging over pluralities (pluralities as many). ${ }^{7}$

(7) a. John ate something, the cookies.

b. I brought you something, a cup, a plate, and a fork.

In fact, -thing-quantifiers can be used to range over absolutely everything and are typically used in statements of absolute generality (see Rayo and Uzquiano 2007).

\footnotetext{
${ }^{5}$ The overt light noun thing displays a syntactic count feature not shared by THING, which explains why thing can appear with every and is excluded in *littlething, *morething. This, however, is an uninterpreted syntactic feature. In section 4, we will see that -thing always acts as a mass noun, even if it introduces a countable domain.

${ }^{6}$ A reviewer has pointed out that certain count NPs are possible in such contexts-for example, those with present and drink as head nouns.
}

(i) a. Mary bought a nice present for her mom, bath salts.

b. Mary drank a drink she likes, lemonade.

Those count NPs are also possible in predicative position with mass NPs in subject position, on a generic, type-referential reading.

(ii) a. Bath salts are a nice present for a girl.

b. Lemonade is a drink that I would not offer in the evening.

However, these are not counterexamples to the view that -thing is able to act as a mass noun. There is something special about the count nouns present and drink-namely, that they convey countability on the basis of function rather than inherent properties of the entity being described (e.g., having a boundary or other form of unity). As a result, functional count nouns of this sort present significant challenges to received views of the mass/count distinction that are based on mereological properties of entities. But they do not present a challenge to the present argument, that something has mass uses. Note that other count nouns that convey countability on the basis of the inherent unity of an entity, such as object or entity, are equally impossible in contexts such as (ii).

(iii) ???John bought an object / an entity, bath salts.

${ }^{7}$ The existence of plural quantifiers in natural language has, incorrectly, been questioned by some philosophers (Linnebo 2017). 
(8) a. Are there quantifiers ranging over absolutely everything?

b. Nihilists doubt the existence of everything there is.

c. The world is everything there is. (Wittgenstein)

In certain contexts, -thing is restricted to inanimate objects (??John saw something, namely Mary). This can be explained as a blocking effect, given the availability of the more specific somebody in the same sentential context. That is, if for an expression $\mathrm{X}$, the language contains an expression $\mathrm{Y}$ with a more specific meaning than that of $\mathrm{X}$, then the choice of $\mathrm{X}$ instead of $\mathrm{Y}$ indicates that $\mathrm{X}$ is to be understood with a meaning complementary to that of $\mathrm{Y}$. The light noun THING is thus the most general noun, applying to anything whatsoever.

There are certain argument positions in which only light NPs, not full NPs, may appear. Some of them are of considerable interest philosophically — in particular, the complement position of certain attitude verbs (say, think, claim) and of copula verbs and intensional transitive verbs. ${ }^{8}$

(9) a. John said something nice /*some nice thing.

b. Mary thought / assumed something / *some thing.

c. John became something admirable, a hero / *some admirable thing.

d. John is looking for something, an assistant / *some thing, an assistant.

For that reason, such quantifiers have been considered nonnominal quantifiers (Rosefeldt 2008). While that label is obviously incorrect syntactically, the syntactic category distinction between light NPs and full NPs is yet to be explored for the semantics of nonreferential complements.

It has been proposed that light nouns come with no syntactic features or functional projections (Collins 2007). This certainly holds for gender features. Light nouns lack the gender features of full nouns, as can be seen from the absence of gender agreement between the apparent feminine light noun and an adjective in French (quelque chose de bon / *de bonne) and Italian (qualcosa di buono / *di buona), as well as in the obligatory neuter gender of adjectives modifying PERSON light NPs in German (niemand interessantes / *interessanter / *interessante 'no one interesting (neut.) / (masc.) / (fem.)'). Given that light nouns are not marked for gender, a modifying adjective needs to take neuter - that is, unmarked-gender.

Light quantifiers ranging over locations have the syntactic peculiarity of not requiring or even allowing a spatial preposition in particular cases.

(10) John worked (*at) someplace.

In the literature, this is generally accounted for by having someplace move to Spec,P, allowing the P to stay empty (Kayne 2005, Collins 2007, Terzi 2010a,b). This means that where, when, somewhere, every, and so on are PPs, not NPs.

There are pronouns corresponding to light quantifiers, namely, that, what, who, where, and when. That and what are pronominal counterparts of something, which means they are able, in principle, to stand for anything whatsoever. This is most obvious in the use of what in questions,

\footnotetext{
${ }^{8}$ See Moltmann 2003, 2013a for a discussion and semantic analysis of light quantifiers as "special" or "nominalizing" quantifiers with the various sorts of intensional predicates with which they may occur.
} 
which allows anything whatsoever to be mentioned as an answer, as long as the presuppositions of the predicate permit it.

(11) What did John see? He saw Mary.

That, what, who, and where are best not considered light nouns themselves, though. Thus, Kayne (2010:chap. 5) argues that where is in fact a determiner combining with the silent noun PLACE or THING, so that (12a) is in fact (12b).

(12) a. John went where Mary went.

b. John went where-PLACE Mary went.

Similarly, there will be there-PLACE, what what-THING, that that-THING, and when whenTIME, respectively. ${ }^{9}$

In German, the counterpart of where, wo, is more obviously able to combine with THING: in relative clauses modifying THING-NPs (alles 'everything', etwas 'something', nichts 'nothing', das 'that'), wo rather than was (as a relative pronoun; see below) appears with prepositions (in fact, postpositions) (Noonan 2017). This is illustrated in (13) with 'everything' and 'that'.

(13) a. alles, wovon / womit / worüber /*von was / *mit was / everything where.of / where.with / where.about / of what / with what /

*über was about what

'everything of which / with which / about which / of which / with which / about which'

b. das, wovon / *was von / *von was / ??von dem

that where.of / what of / of what / of which

'that of which'

Similarly, da appears as counterpart of das 'that' with prepositions (davon 'of that', darüber 'about that', damit 'with that'). Where and wo/da thus are determiners able to combine with both light nouns PLACE and THING.

As mentioned already, in contrast to their English counterparts, German light quantifiers do not involve an overt light noun. Alles 'everything', etwas 'something', and nichts 'nothing' are THING-quantifiers, and thus their actual structure is [alles THING], [etwas THING], and [nichts THING]; jeder 'everyone', jemand 'someone', and niemand 'no one' are PERSON-quantifiers. Alles as a THING-quantifier is as potentially unrestricted as English everything. Light nouns, in their overt or silent versions, thus are selected by particular quantifiers or pronouns.

\footnotetext{
${ }^{9}$ PLACE will also be part of somewhere since where here is not a light noun either (and likewise for German irgendwo 'somewhere').
} 


\section{$2 W$-Pronouns in German}

German light quantifiers and pronouns show a peculiarity that is particularly important in the context of this article. This concerns the choice between two sorts of relative pronouns:

1. w-pronouns, which consist of the neuter pronouns was and wo

2. d-pronouns, which consist of the gender-marked pronouns der (masc.), die (fem.), and das (neut.). ${ }^{10}$

There are some contexts for which the choice between $d$-pronouns and $w$-pronouns varies among speakers, and various subtle semantic parameters seem to be at play. However, the following generalizations capture stable intuitions (Brandt and Fuß 2017, 2019). In general, NPs headed by full nouns choose $d$-pronouns, illustrated in (14) with only a neuter noun (Objekt), as was is neuter. $^{11}$

(14) Maria nahm jedes / ein / kein Objekt, das /*was sie fand. Maria took every / some / no object that / what she found 'Maria took every / some / no object that she found.'

By contrast, neuter light quantifiers and pronouns such as alles 'everything', das 'that', nichts 'nothing', etwas 'something', viel 'much', and das meiste 'most' select $w$-pronouns. ${ }^{12}$

(15) a. Alles, was /*das Hans besitzt, ist schön. everything what / that Hans owns is beautiful 'Everything that Hans owns is beautiful.'

${ }^{10}$ The choice between $d$-pronouns and $w$-pronouns was described by various early German grammarians, such as Behagel, Curme, and Cutting; see Brandt and Fuß 2017, 2019 for detailed references.

${ }^{11}$ Nominalized superlative adjectives also take $w$-pronouns rather than $d$-pronouns.

(i) das Beste, was / *das 'the best that'

Brandt and Fuß (2017) argue that this is due to an implicit alles (which selects $w$-pronouns) in superlatives (the best $=$ better than everything).

For at least some speakers, including myself, mass NPs that are not definite also select or at least prefer $w$-pronouns.

(ii) etwas / alles Wasser (mass, neut.), was / ??das mit Rosenöl vermischt ist 'some / all water that is mixed with rose oil'

For such speakers, NPs such as all das Wasser 'all that water' permit both $w$-pronouns and $d$-pronouns, the former obviously being selected by all and the latter by das.

(iii) all das Wasser, was / das er trinkt

'all that water that he drinks'

However, since those judgments are not represented in the corpus study of Brandt and Fuß (2017), I will leave the issue aside.

${ }^{12}$ Light adverbial pronouns and quantifiers involving TIME and PLACE such as dann 'then' and irgendwo 'somewhere' choose $w$-pronouns.

(i) a. Hans kommt dann, wenn er will $/ *_{\text {zu dem }}$ er will. Hans comes then when he wants / to which he wants 'Hans will come when he wants.'

b. Maria ist irgendwo, wo / *an dem die Sonne scheint. 'Maria is somewhere, where / in which the sun is shining.' 
b. Etwas, was /*das Hans ärgert, ist der Lärm. something what / that Hans bothers is the noise 'Something that bothers Hans is the noise.'

c. Nichts, was / *das Hans sagte, ist wahr. nothing what / that Hans said is true 'Nothing that Hans said is true.'

d. Hans sagte mir nichts, wovon / ??von dem ich nicht schon wusste. Hans told me nothing where.of / of that I not already knew 'Hans told me nothing that I did not already know about.'

e. Das meiste, worüber / ???über das er sprach, war uninteressant. the most where.about / about that he talked was uninteresting 'Most of what he talked about was uninteresting.'

Not all light NPs select $w$-pronouns, though. In particular, those with the light noun PERSON do not.

(16) a. Jeder / Niemand / Jemand, der /*was mich kannte, kam. everybody / no.one / someone who / what me knew came 'Everybody / No one / Someone who / what knew me came.'

b. Jeder, von dem / *wovon / *von was Maria gesprochen hatte, kam. everybody of whom / where.of / of what Maria talked had came 'Everybody, of whom / where / what Maria had talked, came.'

The difference between light nouns and full nouns is also evident when neuter pronouns are contrasted with silent full nouns and silent light nouns as in (17) from Brandt and Fuß 2017:212.

(17) a. Das Bild, das Peter gekauft hat, war teurer als das, das Maria the picture that Peter bought has was more.expensive than that that Maria gekauft hat.

bought has

'The picture that Peter has bought was more expensive than the one that Maria has bought.'

b. Das Bild, das Peter gekauft hat, war teurer als das, was Maria the picture that Peter bought has was more.expensive than that what Maria gekauft hat.

bought has

'The picture that Peter has bought was more expensive than the one that Maria has bought.'

(17a) compares the picture Peter bought with the picture Maria bought; (17b) compares it with the things Maria bought. In (17a), das is followed by a silent full noun (das $\mathrm{N})$; in (17b), it is followed by a silent light noun (das THING).

The standard view about the choice of relative pronouns in German is that $w$-pronouns are subject to an elsewhere condition: $w$-pronouns are chosen just in case the condition for $d$-pronouns 
is not met, namely, that the head noun be gender-marked ([+masculine], [+feminine], [+neuter] $(=[-$ masculine,- feminine $])$ (Brandt and Fuß 2017, 2019, and references therein). The condition holds for full nouns as well as jeder / jemand / niemand, and so on. This, though, poses difficulties for the view that light nouns do not carry gender features. The lack of gender marking on THING, TIME, and PLACE leads to a default classification as neuter. But this does not apply to PERSON, which selects $d$-pronouns. I will argue that what distinguishes PERSON from the other light nouns is its status as a noun ranging over a countable domain. This requires the elsewhere condition on $w$-pronouns to be modified as follows:

(18) Condition on the choice of German relative pronouns (d-pronouns and $\mathrm{w}$-pronouns) $D$-pronouns appear with head nouns carrying the feature [+masculine], $[+$ feminine $]$, [+neuter], or [+count]; $w$-pronouns appear elsewhere.

I will turn to the count/noncount status of light nouns after discussing a related phenomenon, the support of plural anaphora.

\section{Plural Anaphora in English and German}

The selection of $w$-pronouns by light nouns goes along with a failure to support plural anaphora. This requires a few words about plural anaphora in German and in English and an important difference between the two languages. The plural anaphor sie in German generally requires antecedents that are syntactically plural, as in $(19 \mathrm{a}-\mathrm{c})$. By contrast, English they allows antecedents that are syntactically mass, though semantically plural-namely, in particular conjunctions of mass NPs, as the acceptable English translations of $(19 a-c)$ illustrate.

(19) a. Hans hat Mehl und Reis gekauft. Er hat $*$ sie $/ \checkmark$ es / $\checkmark$ das / $\checkmark$ beides bezahlt. Hans has flour and rice bought he has them / it / that / both paid.for 'Hans bought flour and rice. He paid for them / it / that / both.'

b. Maria hat das Silber und das Gold betrachtet. Sie hatte *sie / $\checkmark$ es noch nicht Maria has the silver and the gold looked.at she had them / it yet not gesehen.

seen

'Maria has looked at the silver and the gold. She had not seen them / it before.'

c. Der Regen und der Schnee, Maria hat beides / das / *sie gesehen.

the rain and the snow Maria has both / that / them seen

'The rain and the snow, Maria has seen both / that / them.'

Instead of the plural pronoun sie, German allows only es 'it', das 'that', or beides 'both' ${ }^{13}$ Beides is syntactically singular (mass), yet behaves like a plural semantically. ${ }^{14}$

${ }^{13}$ Somewhat colloquial German also allows die 'the / they' in the contexts (19a-b). Die is homophonous with the plural determiner and also acts as a demonstrative without linguistic antecedent. I take die to be a plural demonstrative (referring to a contextually given plurality), not a pronoun. It is thus not subject to the condition on pronouns in German in (21).

${ }^{14}$ See Moltmann 2021 on beides. 
Let us assume that plural pronouns are in fact determiners, as suggested by Kayne (2010), following Postal (1966). Then the plural determiners they / sie select semantic plurality in English, but syntactic plurality in German. This is made more precise in (20), using the notion of an integrated whole (Simons 1987, Moltmann 1997), a notion of unity of entities that is independent of syntactic singularity.

(20) a. For a discourse context $\mathrm{c}$ and an NP X, $[\text { they } \mathrm{X}]^{\mathrm{c}}$ is defined only if an utterance of $\mathrm{X}$ is part of $\mathrm{c}$ and the semantic value of $\mathrm{X}$ is a plurality of integrated wholes.

b. For a discourse context $\mathrm{c}$ and an NP X, $[\text { sie } \mathrm{X}]^{\mathrm{c}}$ is defined only if an utterance of $\mathrm{X}$ is part of $\mathrm{c}$ and [+plural].

Referents of singular count NPs are generally integrated wholes, but referents of definite mass NPs, such as the silver, are as well. The silver is an integrated whole in the sense that it is the maximal entity (in the context) whose parts share the property of being silver (Simons's (1987) notion of an FF-integrated whole; see also Moltmann 1997).

Why do English and German differ with respect to the antecedents of plural anaphors? This appears related to the fact that gender features are determined syntactically in German and semantically in English. In German, gender as a syntactic feature of nouns is fixed in the lexicon, rather than being based on the nature of the referent, as in English. ${ }^{15}$ Moreover, German personal pronouns (er 'he', sie 'she', es 'it') and determiners (der, die, das) require syntactic agreement with the gender of the relevant NP. (20b) is then part of a more general condition according to which German pronouns select NPs on the basis of syntactic features of their antecedents. ${ }^{16}$

\section{(21) Condition on English and German anaphoric pronouns}

a. For an English pronoun p, an NP X, and a discourse context c, [p X $]^{\mathrm{c}}$ is defined only if an utterance of $\mathrm{X}$ is part of $\mathrm{c}$ and the semantic value of $\mathrm{X}$ satisfies the features of $\mathrm{p}$.

b. For a German pronoun $\mathrm{p}$, an NP X, and a discourse context $\mathrm{c},[\mathrm{p} \mathrm{X}]^{\mathrm{c}}$ is defined only if an utterance of $\mathrm{X}$ is part of $\mathrm{c}$ and $\mathrm{X}$ agrees in syntactic features with $\mathrm{p}$.

What is important in the present context is the observation that conjunctions of light NPs that select $w$-pronouns also fail to support plural anaphora, as (22a-b) show. ${ }^{17}$

${ }^{15}$ Uses of she / her for ships in English may be set aside as peculiarities of the individuation of certain artifacts.

${ }^{16}$ As a reviewer points out, they / them may take someone / a student as antecedent in colloquial, recent English. On this use, they / them seems to have lost its plural feature, exploiting the fact that the plural does not come with gender marking in English.

${ }^{17}$ Bare mass nouns as names of kinds in German also require $w$-pronouns (for the relevant group of speakers, see footnote 11).

(i) a. Magnesium, was / ???das lebenswichtig ist, ist ein wichtiges Metal. magnesium which / that vital is is an important metal

'Magnesium, which is essential for life, is an important metal.'

b. Reis, was / ???der gesünder ist als Weizen, ist nicht teuer.

rice which / that healthier is than wheat is not expensive

'Rice, which is healthier than wheat, is not expensive.'

Moreover, conjunctions of bare mass nouns in their kind-referring use do not support plural anaphora. 
(22) a. Hans kann sich an das erste und das zweite erinnern, was Maria gesagt hat. Hans can himself at the first and the second recall which Maria said has Max kann sich daran / *an sie auch erinnern.

Max can himself there.at / at them too recall

'Hans can recall the first thing and the second thing Maria said. Max can recall them / that too.'

b. Hans hat etwas gebaut und Maria hat etwas gezeichnet. Peter hat (das)

Hans has something built and Maria has something drawn Peter has (that)

beides / *sie bewundert.

both / them admired

'Hans has built something and Maria has drawn something. Peter has admired (that) both / them.'

(22a) contrasts with (23), with the full noun Ding, which takes $d$-pronouns and supports plural anaphora.

(23) Hans kann sich an das erste und das zweite Ding erinnern. Max kann sich an Hans can himself at the first and the second thing recall Max can himself at sie auch erinnern.

them too recall

'Hans can recall the first thing and the second thing. Max can recall them too.'

Light nouns that select $w$-pronouns thus parallel mass nouns in their failure to support plural anaphora. This indicates that the light noun THING sides with mass nouns rather than with count nouns, or, more carefully, has "noncount" status. The next section will provide further arguments for the noncount status of THING as well as of the light nouns TIME and PLACE. This status will then play an important role in explaining the behavior of German names with respect to relative pronoun selection and plural anaphora support.

(ii) a. Gold und Silber werden zum Schmuckherstellen verwendet. *Sie glänzen. gold and silver are to.the jewelry.making used they shine 'Gold and silver are used to make jewelry. They are shiny.'

b. Magnesium und Eisen sind lebenswichtig. Jeder braucht $*$ sie $/ \checkmark$ das. magnesium and iron are vital everyone needs them / that 'Magnesium and iron are essential for life. Everyone needs them.'

Bare mass nouns remain mass NPs even if they refer to a unique, well-individuated kind.

Note that even feminine and masculine kind-referring mass NPs take $w$-pronouns (for the relevant group of speakers), as the inflection of the adjectival modifiers in (iii) indicates.

(iii) a. Brauner Reis, was / ???der gesünder ist als Weizen, ist nicht teuer. brown (masc.) rice which / that healthier is than wheat is not expensive 'Brown rice, which is healthier than wheat, is not expensive.'

b. Große Weisheit, was / ???die nur wenige besitzen, ist selten. great (fem.) wisdom which / that only few possess is rare 'Great wisdom, which only few possess, is rare.' 


\section{The Noncount Status of the Light Nouns THING, TIME, and PLACE}

Light nouns do not come with a syntactic mass/count distinction-a distinction that is to some extent arbitrary, with full nouns reflecting at best "grammaticalized individuation" (compare English shoes - footwear, rice grains - rice) (Rothstein 2017). Rather, the status of a light noun as count or noncount is strictly determined by semantic criteria. Given such criteria, PERSON obviously classifies as count, but not so THING, TIME, and PLACE.

First of all, we have seen that there are both mass and apparent count uses of THING. Though the light noun -thing contrasts with the full noun thing, which has only a count use, there are apparent count uses of -thing as well. -thing in fact has a plural: several things. Several things can appear in contexts in which only light NPs can appear, such as the object position of a verb of saying.

(24) a. He said something nice.

b. ???He said some nice thing.

c. He said several nice things.

Syntactically, though, the plural things behaves like the full noun thing, with the adjective preceding the noun. German, which lacks an overt version of the light noun THING, forms a plural of THING using the plural of the full noun Ding, but with the light noun meaning of THING.

(25) a. Er hat etwas / *ein Ding gesagt.

he has something / a thing said

'He said something / a thing.'

b. Er hat mehrere Dinge gesagt.

he has several things said

'He said several things.'

Like the English plural things, Dinge as in (25b) syntactically remains a full noun, selecting $d$ pronouns. $^{18}$

THING-quantifiers in German also appear to have singular count uses, as is apparent with cardinal or ordinal numerals in eines 'one thing', das eine 'the one thing', and das erste 'the first thing'.

(26) a. Hans hat eines vergessen, dass er ein Visum braucht. Hans has one forgotten that he a visa needs 'Hans forgot one thing, that he needs a visa.'

b. Das eine, was Hans vergessen hat, ist, dass er ein Visum braucht. the one what Hans forgotten has is that he a visa needs 'The one thing that Hans forgot is that he needs a visa.'

\footnotetext{
${ }^{18}$ Other languages do not seem to display a syntactic difference between the singular and plural of THING. For example, the French light noun chose and the Italian noun cosa have count uses and a plural from the same paradigm (plusieurs choses 'several things', molte cose 'many things'). This indicates that light nouns do not as such lack number; only silent THING does so.
} 
c. das erste, was Maria gesagt hat the first what Maria said has 'the first thing Maria said'

Thus, THING, in English and in German, has both mass and count versions and a plural borrowed from the full noun homophone.

However, there is something special about the count use of THING. On that use, THING need not pick up on any inherent countability of an entity, unlike the singular full count nouns thing and Ding. Rather, THING, on a count use, may impose countability on things that are not per se countable, such as the referents of mass or plural NPs. This is illustrated in $(27 a-b)$, which also illustrate the contrast between THING and the full noun Ding. ${ }^{19}$

(27) a. Hans hat eines / ???ein Ding nicht gegessen, die Bohnen (plural) / den Hans has one / one thing not eaten the beans / the Reis (mass).

rice

'Hans failed to eat one thing, the beans / the rice.'

b. Das eine / ???Das eine Ding, was Hans nicht mag, sind Bohnen (plural) / the one / the one thing what Hans not likes are beans / Reis (mass).

rice

'The one thing Hans does not like is beans / rice.'

On such a count use, the light noun THING can even count a plurality of two entities as one, unlike the full noun Ding.

(28) a. Das eine / einzige / ???eine Ding / ???einzige Ding, was Maria vergessen hat, the one / unique / one thing / unique thing what Maria forgotten has waren die zwei Taschen.

were the two bags

'The one / only thing that Maria forgot was the two bags.'

b. Ich habe Maria an das eine / das einzige / ???das eine Ding / ???das einzige I have Maria at the one / the unique / the one thing / the unique Ding erinnert, das sie vergessen hatte, die beiden Taschen im Schrank. thing reminded that she forgotten had the two bags in.the closet 'I reminded Maria of the one thing / the only thing she forgot, the two bags in the closet.'

\footnotetext{
${ }^{19}$ The "reifying" function of THING can certainly be related to the nominalizing function of THING-quantifiers when they occur in place of nonreferential complements, such as that-clauses, predicative complements, and complements of intensional transitive verbs, as discussed in Moltmann 2013a.
} 
THING contrasts in that respect with the light singular count noun PERSON, which cannot be used to refer to a plurality of people, as the impossibility of the collective predicate in (29) makes clear.

(29) ???Everyone / Someone met in the room.

On such singular count uses, THING acts like a numeral classifier in classifier languages, on a view such as Rothstein's (2017), mapping a domain not specified for countability onto a countable one. That is, THING imposes countability by picking up on a distinguishing property of elements of the domain, whether they are stuff or things. THING is then both mass and count in the sense that it applies to a domain not specified for countability and may map it onto one that is. Given that, the selection of $w$-pronouns by THING-quantifiers can be attributed to the mass status (on one side) of (singular) THING. ${ }^{20}$

Apart from the behavior of THING with mass nouns, there are general philosophical reasons to regard the light noun thing as a mass noun: generally, counting requires a sortal, giving the identity conditions of the things being counted (Frege 1884). Given that view, there could not be a count predicate for everything there is. This appears to be reflected also in the fact that count quantifiers such as many, few, and a few do not allow THING as restriction; they only allow the light count noun PERSON, or else a deleted full noun, requiring an antecedent (section 1).

The light noun TIME is clearly noncount semantically, as its overt counterpart time is a mass noun. There are a number of reasons to consider it a noncount noun [-count]. First of all, its manifest version in someplace does not come with a plural (Collins 2007). Yet someplace / somewhere can appear in contexts where a plural would be strongly preferred. Thus, if John and Mary live in different places in Europe, (30a) is still acceptable, but (30b) is not, as opposed to (30c).

(30) a. John and Mary live somewhere in Europe.

b. John and Mary live in some place in Europe.

c. John and Mary live in some places in Europe.

The light noun PLACE satisfies standard semantic criteria for mass nouns (Pelletier and Schubert 1989, 2003): it is cumulative (the sum of two places is again a place) as well as divisive (a part of a place is again a place). Even apart from standard extensional mereological criteria for mass nouns, there are fundamental ontological differences between places and individuals, which rank places below the level of individuals in terms of degrees of individuation and motivate a classification of PLACE as noncount. Thus, Strawson (1959) distinguishes a conceptually (and perhaps developmentally) earlier stage of the use of language, namely, as a feature-placing language. A feature-placing language does not involve reference to individuals; it involves only the placing

\footnotetext{
${ }^{20}$ There is also a view on which the mass/count distinction is not binary, but may involve various criteria (Kulkarni, Treves, and Rothstein 2020). Different criteria may then fail to classify THING and PLACE together with the count noun PERSON.
} 
of a feature (quality) at a location. Locations thus are prior, conceptually and possibly developmentally, to individuals. Individuals that are material objects are individuated in terms of persistence conditions across different locations and at different times. Locations form a basis for the individuation of individuals, but not conversely. ${ }^{21}$

To summarize, light nouns come with a mass/count distinction that is strictly grounded in semantic or ontological properties of their denotations, with only PERSON having the status of a light count noun (as well as the light noun HOUSE, as we will see in the next section).

\section{Type 1 Names in German: Names for People, Buildings, and Places}

German names exhibit a remarkable pattern in the selection of $w$-pronouns and plural anaphora, displaying a sharp divide between person names on the one hand and place names on the other. In addition, "productive" names for times, numbers, and expression types side with names for places.

Two types of proper names need to be distinguished, for German as well as English and similar languages: type 1 names and type 2 names, as I will call them. Type 1 names take the form of simple nouns in argument position (English John or London). ${ }^{22}$ Type 2 names require a determiner in argument position (English the Hudson, the Parthenon).

In German, type 1 names for people and type 1 names for places (cities, villages, countries, and continents) differ in two respects:

1. selection of relative pronouns: $d$-pronouns (der, die, das) or w-pronouns (was, wo), and

2. plural anaphora support by a conjunction of proper names as antecedent.

The choice of $d$-pronouns goes along with support of plural anaphora, whereas the choice of $w$ pronouns goes along with failure to support plural anaphora. ${ }^{23}$

Here are the relevant generalizations regarding person names. Proper names for people (and animals) select $d$-pronouns.

(31) a. Hans, der /*was

Hans who / what

'Hans, who'

${ }^{21}$ The full noun place is a count noun of the type fence, wall, and entity, nouns that satisfy mereological criteria for mass nouns, yet are count (Moltmann 1997:22, Rothstein 2017). With the full noun place, it is the contextually given boundary or integrity of a place that ensures countability.

${ }^{22}$ I will not make any particular assumptions about the syntactic structure of type 1 names. See Longobardi 1994 and subsequent work for a discussion of the syntax of type 1 names. On Longobardi's view, names move to D position (possibly only at LF). Head movement to D is no longer available on the view developed here, according to which type 1 names come with a silent light noun that forms the head of the DP. However, movement of the light NP (name - light noun) to Spec,D is available. See later in this section.

${ }^{23}$ The generalizations hold at least for standard German spoken in southern Germany. For some German speakers, $d$-pronouns and $w$-pronouns are interchangeable for place names as well as in other contexts.

A certain regional and colloquial German (southern Germany) allows definite determiners with names (der Hans 'the Hans', die Maria 'the Maria'). However, there does not seem to be a correlation between the use of definite determiners with names and relative pronoun choices. There is nothing colloquial about the choice of one relative pronoun over another. 
b. Maria, die /*was

Maria who / what

'Maria, who'

Besides masculine and feminine names, diminutive names — which are syntactically neuter — also select $d$-pronouns.

(32) a. Er zeigte uns Fritzchen, das /*was wir noch nicht gesehen hatten.

he showed us Fritzchen that / what we yet not seen had

'He showed us little Fritz, whom we had not seen.'

b. Mariechen, das /*was wir sehr mögen, kann uns helfen.

Mariechen that / what we very like can us help

'Little Marie, whom we like a lot, can help us.'

There are also proper names for inanimate objects that select $d$-pronouns, for example, proper names for castles and churches.

(33) a. Sanssouci, das / ??was kleiner ist als Versailles

Sanssouci that / what smaller is than Versailles

'Sanssouci, which is smaller than Versailles'

b. Zarskoe Selo, das / ??was größer ist als Pavlowsk

Tsarskoe Selo that / what bigger is than Pavlovsk

'Tsarskoe Selo, which is bigger than Pavlovsk'

c. Notre Dame, das / ??was beinahe durch ein Feuer zerstört wurde

Notre Dame that / what almost by a fire destroyed was

'Notre Dame, which was almost destroyed by fire'

Names for castles and churches are syntactically neuter. This is shown by the fact that a definite determiner that is required by an adjectival modifier of the name must be neuter (regardless of the gender of a suitable sortal noun: Kirche 'church' is feminine, Palast 'palace' masculine).

(34) a. das / *die schöne Notre Dame 'the beautiful Notre Dame'

b. das / *der erstaunliche Zarskoe Selo

'the amazing Tsarskoe Selo'

Here, the choice of neuter gender is based on the nature of the referent.

Names for places, cities, countries, and continents select $w$-pronouns, not $d$-pronouns. ${ }^{24}$

\footnotetext{
${ }^{24}$ There is one type of exception to the generalization for those speakers and that is plural country names such as die Niederlande 'the Netherlands', which select $d$-pronouns.

(i) die Niederlande, die 'the Netherlands, which'

Here the sortal appears overt (-lande), and the names may better be classified as type 2 names, which come with a definite determiner; see section 7 .
} 
(35) a. München, was / ???das ich sehr gut kenne

Munich what / that I very well know

'Munich, which I know very well'

b. Ich kenne Berlin, was / ???das du ja nicht kennst.

I know Berlin what / that you PART not know

'I know Berlin, which you do not know.'

c. Ich liebe Italien, was / ???das dir ja auch gut gefällt.

I love Italy what / that you PART too well pleases

'I love Italy, which pleases you too.'

(36) a. Ich kenne Australien, was / ???das du ja nicht kennst.

I know Australia what / that you PART not know

'I know Australia, which you do not know.'

b. Asien, was / ???das weit größer als Europa ist

Asia what / that far bigger than Europe is

'Asia, which is far bigger than Europe'

The same contrast holds for complex relative pronouns of the sort wovon 'of which', as opposed to von dem 'of which'.

(37) a. Berlin, womit / ??mit dem ich mich schon lange befasse, ist ein

Berlin where.with / with which I myself already long occupy is an interessantes Thema für ein Projekt.

interesting topic for a project

'Berlin, with which I have occupied myself for a long time, is an interesting topic for a project.'

b. England, wovon / ??von dem er eine Stunde lang sprach

England where.of / of which he an hour long spoke

'England, of which he spoke for an hour'

c. Afrika, worüber / ??über das wir uns lange unterhalten haben

Africa where.about / about which we ourselves long talked have

'Africa, which we talked about for a long time'

Turning then to plural anaphora, in German (as in English) conjunctions of proper names for people are unproblematic as antecedents for plural anaphora.

(38) Anna mag Hans und Franz. Bill mag sie auch.

'Anna likes Hans and Franz. Bill likes them too.'

The same holds for names of churches and palaces.

(39) a. Ich kenne Notre Dame und Sainte Chapelle. Sie sind beide sehr schön.

'I know Notre Dame and Sainte Chapelle. They are both very beautiful.'

b. Zarskoe Selo und Pavlowsk, sie befinden sich in der Nähe von Sankt Petersburg.

'Tsarskoe Selo and Pavlovsk, they are located in the vicinity of Saint Petersburg.' 
By contrast, conjunctions of German names for places do not support plural anaphora. Rather, for the purpose of anaphoric reference to a conjunction of place names, a definite plural NP with a sortal head noun must be chosen. ${ }^{25}$

(40) a. Ich kenne Berlin und München. Anna kennt ??sie / $\checkmark$ diese Städte auch. 'I know Berlin and Munich. Anna knows them / those cities too.'

b. Ich mag Frankreich und Italien. Marie mag ??sie / $`$ diese Länder auch. 'I like France and Italy. Marie likes them / those countries too.'

Conjunctions of close appositions with place sortals as head nouns do support plural anaphora, as expected.

(41) Ich kenne die Stadt Berlin und die Stadt München. Maria kennt sie auch.

'I know the city of Berlin and the city of Munich. Maria knows them too.'

The conditions on plural anaphora support are different in English. Conjunctions of English place names are unproblematic as antecedents for plural anaphora.

(42) a. I know Berlin and Munich. Mary knows them too.

b. I like France and Italy. Mary likes them too.

c. I would like to visit Australia and Africa. Mary would like to visit them too.

Only in certain larger constructions can German place names go with $d$-pronouns and support plural anaphora. One of them is close apposition, where the $d$-pronoun is selected by the full head noun, with which it agrees in gender.

(43) a. die Stadt München, die /*was ich gut kenne the city Munich which / what I well know 'the city of Munich, which I know well'

b. Die Städte München und Berlin, ich kenne sie gut. 'The cities of Munich and Berlin, I know them well.'

Another construction involves temporal modification.

(44) das Berlin der 20iger Jahre, das /*was ich nicht kenne the (neut.) Berlin of.the 20 years which / what I not know 'the Berlin of the '20s, which I do not know'

Here, the proper name most plausibly has undergone meaning shift from a name referring to a place to a noun expressing a sortal concept for temporal stages of the place. The sortal noun is count, allowing for the plural, as in die Berlins der verschiedenen Epochen 'the (different) Berlins of the different periods'.

Why do place names in German select $w$-pronouns and fail to support plural anaphora? Given the previous section, NPs that select $w$-pronouns and fail to support plural anaphora are

${ }^{25}$ Again, die is possible as well in $(40 a-b)$, in the relevant colloquial German. See footnote 23. 
those that involve as head a light noun that is noncount, such as THING. German place names themselves can hardly be considered noncount, since they stand for single, well-distinguished entities. Cities, countries, and continents are clearly countable, or at least they are treated as such in the way we ordinarily think and talk about them. The classification of German place names as noncount, however, can be attributed to the presence of a silent PLACE. Like THING, the light noun PLACE is a mass noun, contrasting with PERSON. If silent light nouns are type 1 names, the difference in count status between names for places and names for people in German is explained. ${ }^{26}$ A silent light noun thus should constitute the head of a type 1 name, as in (45), determining the count status of the entire DP.

(45) a. $\left[\left[\text { Hans }[\text { PERSON }]_{\text {Nlight }}\right]_{\text {NlightP }}\right]_{D P}$

b. $\left[\left[\text { Berlin }[\mathrm{PLACE}]_{\mathrm{Nlight}}\right]_{\mathrm{NlightP}}\right]_{\mathrm{DP}}$

English type 1 names will have the same structures. English differs from German only in that English plural anaphors allow antecedents that are semantically but not syntactically plural.

A syntactic question that arises for type 1 names is why type 1 names do not come with the definite determiner. This question needs to be pursued properly somewhere else. Perhaps the answer may reside in the ability of type 1 names (as light DPs) to move to Spec,D, allowing the determiner to stay unpronounced, as has been proposed for light DPs in general by Collins (2007).

Names for churches and palaces will involve a light noun that, like PERSON, classifies as a count noun. It is plausible that HOUSE is such a light noun. HOUSE functions in various languages as a bare NP, a syntactic role close to that of a light noun (Collins 2007). ${ }^{27}$ Examples are Italian (Sono a casa 'I am home', Vado a casa 'I go home') and French (à la maison 'at home'). ${ }^{28}$ Thus, Sanssouci will have the structure [Sanssouci HOUSE] $]_{\mathrm{NlightP}}$.

\section{Productive Names: Names for Times, Addresses, Numbers, and Expression Types}

Certain names are attributed not arbitrarily, by some form of baptism or on another case-by-case basis, but by a scheme aligned with a productive name-formation process applied to a particular domain of entities. These I will call productive names. Such names generally take $w$-pronouns and do not support plural anaphora, which means they contain noncount light nouns.

Names for times (years, specific months, or dates) are productive names involving a combination of numerals and names for recurring periods of time in a certain order. German names for times take $w$-pronouns and do not support plural anaphora.

${ }^{26}$ For the suggestion that light nouns are part of names, see Kayne 2010:chap. 8, app.

${ }^{27}$ Collins (2007) has argued that home has a light noun use, involving PRO for the relevant possessor ([PRO home]). However, it is more plausible that home in fact has the underlying structure [PRO HOUSE]. Many languages, it seems, do not have a light noun home, but use the noun for 'house' instead (Italian a casa, German zu hause). Alternatively, some languages just use a pronoun or name with a preposition (French chez soi 'at one's (home)', chez Marie 'at Marie's (home)').

${ }^{28}$ Note that overt house can be used to refer to churches: for example, English house of God, German Gotteshaus 'house of God', Italian casa del Signore 'house of the Lord'. 
(46) a. 1968, was / ??das interessanter ist als 1970 1968 what / which more.interesting is than 1970 ' 1968 , what / which is more interesting than 1970'

b. 1968, worüber / ??über das ich einen Artikel geschrieben habe 1968 where.about / about which I an article written have '1968, about which I have written an article'

A close apposition is required to make $d$-pronouns acceptable for names of times.

(47) a. das Jahr 1968, das interessanter ist als 1970 the year 1968 which more.interesting is than 1970 'the year 1968, which is more interesting than 1970'

b. die Jahre 1968 and 1970, über die ich gerade schreibe 'the years 1968 and 1970, about which I am currently writing'

German names for times also fail to support plural anaphora, unlike their English counterparts (as the translations of (48a-b) make clear).

(48) a. Ich habe an 1968 und 1970 gedacht. Maria hat auch an *sie / $\checkmark$ diese Jahre I have at 1968 and 1970 thought Maria has too at them / those years gedacht.

thought

'I have thought about 1968 and 1970. Maria thought about them / those years too.'

b. Anna schlug den dritten und den vierten August vor. Maria schlug *sie $/ \checkmark$ diese Tage auch vor.

'Anna proposed the third and the fourth of August. Maria proposed them / those days too.'

Names for years, days, or months as such could hardly classify as noncount semantically, since they stand for well-individuated temporal units and are part of a conventionalized schema for naming them in a certain order. However, the noncount status of names for times can be attributed to the presence of the light mass noun TIME. ${ }^{29}$ As part of a name, TIME does not tell whether the referent is a year, month, or day. However, the choice of a particular temporal unit as the referent of the name will be part of the naming schema that goes along with the particular type of productive name.

Names for addresses are productive names referring to places. They select $w$-pronouns and fail to support plural anaphora.

(49) a. 1600 Pennsylvania Avenue, was /*das die Adresse des Weissen Hauses ist 1600 Pennsylvania Avenue what / which the address of the White House is '1600 Pennsylvania Avenue, what / which is the address of the White House'

\footnotetext{
${ }^{29}$ One might suggest that 1968 is in fact accompanied by both TIME and YEAR. However, it is unlikely that YEAR is noncount. Note that the full noun year has not only a count noun use, but also a use as a measure noun (as in for several years).
} 
b. 1600 Pennsylvania Avenue und 10 Downing Street, ich merke mir ???sie / $\checkmark$ diese Adressen.

'1600 Pennsylvania Avenue and 10 Downing Street, I will recall them / those addresses.'

This is obviously due to the presence of the light mass noun PLACE in names for addresses. Recall, by contrast, that names for buildings (churches, palaces) involve the light count noun HOUSE and thus are not categorized as place names.

Names for numbers are also productive names, being formed by nominalizing the corresponding numeral adjective (or numeral quantifier). Number words such as two can occur in argument position, as in (50), and thus can, at least syntactically, be used as names. ${ }^{30}$

(50) Two is smaller than four.

German names for numbers take $w$-pronouns and do not support plural anaphora (Moltmann 2013a:chap. 4, 2013b). ${ }^{31}$

(51) zwei, was / ??das kleiner als vier ist two what / which smaller than four is 'two, which is smaller than four'

(52) a. Hans addierte zehn und zwanzig. Maria addierte *sie / $\checkmark$ diese Zahlen auch. 'Hans added ten and twenty. Maria added them / those numbers too.'

b. Zehn und zwanzig sind durch zwei teilbar. *Sie / $\checkmark$ Diese Zahlen sind keine ten and twenty are by two divisible they/ those numbers are no Primzahlen.

prime.numbers

'Ten and twenty are divisible by two. They / Those numbers are not prime numbers.'

${ }^{30}$ In Hofweber 2005 and Moltmann 2013a,b, simple numerals are taken to still have adjectival or quantificational meaning. But see Moltmann 2017 for arguments that their syntactic status is that of a name and no longer that of an adjective or quantifier.

${ }^{31}$ German number words can also appear in the type 2 name construction, in which case, as expected, they take $d$-pronouns.

(i) die Zwei, die / $\quad$ was eine Primzahl ist

the (fem.) two which / that a prime.number is

'two, which is a prime number'

In (i), the feminine gender of die matches the feminine gender of the unpronounced sortal Zahl. Such type 2 number names are restricted to relatively low numbers (iia), a constraint that does not hold for close appositions with an overt head (iib).

(ii) a. die Zehn, ??die Zwanzig, ???die Dreiundzwanzig, ???die Hundert

'the ten, the twenty, the twenty-three, the hundred'

b. die Zahl dreiundzwanzig, die Zahl hundert

'the number twenty-three, the number hundred'

English does not have type 2 number names (just as it does not have type 2 names for lakes). 
The noncount status of number names can be attributed to the presence of the light mass noun THING. ${ }^{32}$ Conjunctions of number words in English do support plural anaphora, as shown by the acceptability of the translations of $(52 \mathrm{a}-\mathrm{b})$, due to the fact that plural anaphors in English require their antecedents to be just semantically, not syntactically plural.

Another type of productive name is pure quotations (in contexts where they act as referential terms). Pure quotations are uses of expressions that appear to involve the formation of expressionreferring names, at least in contexts such as subject position in (53a) and object position in (53b) (which allow replacement by an explicit expression-referring term of the sort 'the name Anna'). ${ }^{33}$

(53) a. Anna ist zweisilbig.

'Anna is disyllabic.'

b. Hans buchstabierte Anna.

'Hans spelled Anna.'

German pure quotations in contexts such as $(54 \mathrm{a}-\mathrm{b})$ take $w$-pronouns rather than $d$-pronouns.

(54) a. Anna, was /*das der Name dieser Frau ist, ist zweisilbig.

Anna what / which the name of.this woman is is disyllabic

'Anna, what / which is the name of this woman, is disyllabic.'

b. Hans buchstabierte ich, was /*das ein Pronomen ist.

Hans spelled $I$ what / which a pronoun is

'Hans spelled $I$, which is a pronoun.'

Moreover, conjunctions of pure quotations in German do not support plural anaphora.

(55) a. Anna und Marie sind zweisilbig. ???Sie sind nicht dreisilbig.

'Anna and Marie are disyllabic. They are not trisyllabic.'

b. Hans schrieb Ich and Du an die Tafel. Bill schrieb ???sie auch an die Tafel.

'Hans wrote I and You on the blackboard. Bill wrote them on the blackboard too.'

German pure quotations thus pattern with mass NPs, which would be puzzling given the nature of expression types. However, the noncount status of pure quotations can be attributed to the presence of the light noun THING in pure quotations when they occur as expression-referring names.

As the translations of (55a-b) illustrate, conjunctions of pure quotations in English do support plural anaphora, which again is due to the fact that English plural anaphora requires semantic plurality, not syntactic plurality.

\footnotetext{
${ }^{32}$ One might think that number names contain a silent light noun NUMBER. NUMBER, however, is less obviously mass since it takes the plural, at least in English (enormous numbers of; Kayne 2005:182).

${ }^{33}$ Pure quotations like those in $(53 \mathrm{a}-\mathrm{b})$ differ from pure quotations as in small clause predicates of verbs of calling and in as-phrases, where they act predicatively rather than referentially. See section 8.
} 


\section{Type 2 Names in German: Names for Mountains, Lakes, Temples, and Stones}

Type 2 names display a different syntactic structure from type 1 names. Type 2 names involve a more specific, full sortal noun, which generally can appear overtly, as well as the definite determiner, which needs to agree with the sortal. German makes use of the type 2 name construction for names for mountains, lakes, temples, and famous precious stones; other languages may make other choices. Below are examples with German names for mountains.

(56) a. der Mont Blanc, der

b. die Zugspitze, die

c. das Erzgebirge, das

In type 2 names for mountains without explicit sortal, the masculine definite determiner matches the masculine gender of the German sortal Berg 'mountain' and obviously indicates its silent presence.

(57) a. der Fujiyama, der

b. der Vesuv, der

c. der Etna, der

The choice of type 2 names for mountains is rather strict. Just knowing that Kailash is the name for a sacred mountain in Tibet, speakers have very firm intuitions that the name cannot occur on its own in argument position, but requires the masculine definite determiner. ${ }^{34}$
a. *Man darf
Kailash nicht besteigen.
one is.allowed Kailash not climb
'One is not allowed to climb Kailash.'
b. *Kailash ist heilig.
'Kailash is sacred.'

(59) a. Man darf den Kailash nicht besteigen.

one is.allowed the Kailash not climb

'One is not allowed to climb the Kailash.'

b. Der Kailash ist heilig.

'The Kailash is sacred.'

The definite determiner is not obligatory with type 2 names, though, when they are used as vocatives.

(60) (*Der) Kailash, endlich erblicke ich dich!

(the) Kailash finally see I you

'(The) Kailash, finally I see you!'

\footnotetext{
${ }^{34}$ There are certain sorts of names for mountains that are exceptions to the generalization. Names for alps, for example, may be feminine (die Jungfrau, die Dent Blanche) or neutral (das Wiesmies). Such names should be considered idiomatic. There are also certain German names for places that come with a definite determiner and should similarly be considered idiomatic (die Camargue 'the Camargue', die Turkei 'Turkey').
} 
In the predicate position of small clause complements of verbs of calling, type 2 names may also occur without a determiner.

(61) Er nannte den Berg Kailash / den Kailash. 'He called the mountain Kailash / the Kailash.'

Whether a determiner appears depends on whether the calling act is directed toward the referent, involving a vocative use of the name, as in (62a), or whether it makes reference to it in the third person, as in (62b).

(62) a. Er wandte sich an den Berg als Kailash.

'He addressed the mountain as Kailash.'

b. Er bezog sich auf den Berg als der Kailash.

'He referred to the mountain as the Kailash.'

Examples of German names for lakes containing an explicit sortal (possibly from a different language) are der Bodensee, der Zürichsee, der Lago Maggiore. Other names for lakes require the masculine definite determiner, whose gender matches the gender of the sortal noun See 'lake'. Again, names for lakes not familiar to a speaker trigger clear intuitions that they must take the masculine definite determiner in argument position. Thus, just knowing that Manasarovar is a name for a lake (the lake next to Mount Kailash, which is equally sacred), speakers know that the name can be used in argument position only with the masculine definite determiner.

(63) der Manasarovarsee / der Manasarovar / der See Manasarovar 'the Manasarovar lake / the Manasarovar / the lake Manasarovar'

(64) a. Ich will *Manasarovar / $\checkmark$ den Manasarovar sehen.

I want Manasarovar / the Manasarovar see

'I want to see Manasarovar / the Manasarovar.'

b. *Manasarovar / Der Manasarovar ist ebenso heilig wie der Berg Kailash.

Manasarovar / the Manasarovar is equally sacred as the mountain Kailash

'Manasarovar is equally as sacred as Mount Kailash.'

In English, names for lakes and mountains are not type 2 names (Lake Garda / *the Gardalake, Mount Vesuvius / *the Vesuvius). This illustrates that the choice between type 1 and type 2 names for particular kinds of entities is language-specific.

Names for temples are type 2 names in both German and English. For a fairly familiar temple name, this is illustrated below. ${ }^{35}$

\footnotetext{
${ }^{35}$ It is remarkable that names for churches and for temples are treated so differently in one and the same language. In German, names for churches are type 1 names, whereas names for temples are type 2 names. Names for temples are less integrated into German than names for churches, presumably because of the dominance of Christianity in German culture.
} 
(65) Wir haben *Parthenon $/ \checkmark$ den Parthenon $/ \checkmark$ den Parthenontempel besichtigt. we have Parthenon / the Parthenon / the Parthenon.temple visited 'We have visited Parthenon / the Parthenon / the Parthenon temple.'

The masculine gender of the definite article indicates the silent presence of the sortal noun Tempel 'temple'. 36

Unlike type 1 names, type 2 names always select $d$-pronouns and support plural anaphora.

(66) der Kailash, der heilig ist the Kailash which sacred is

'the Kailash, which is sacred'

(67) Hans will den Kailash und den Manasarovar sehen. Maria will sie auch sehen. Hans wants the Kailash and the Manasarovar see Maria wants them too see 'Hans wants to see the Kailash and the Manasarovar. Maria wants to see them too.'

Concerning the syntactic structure of type 2 names, I will simply assume that the overt or silent full sortal noun forms the head of a compound, as in (68a) and (68b).

(68) a. der $\left[\text { Manasarovar }[\text { See }]_{\mathrm{N}}\right]_{\mathrm{NP}}$

b. der $\left[\text { Manasarovar }[\mathrm{e}]_{\mathrm{N}}\right]_{\mathrm{NP}}$

Such a compound structure is obligatory when forming new type 2 names whose sortal is not understood from the context-for example, names for famous precious stones (der Hope-Diamant 'the Hope Diamond', der Rockefeller-Smaragd 'the Rockefeller Emerald'). ${ }^{37}$

The sortal in type 2 names can hardly be considered a light noun, given the variety and culture-specificity of the sortals such names involve. This may present a difficulty for the generalization that only light nouns, not full nouns, can remain silent without an antecedent (Kayne 2005). There is a plausible extension of the notion of antecedent, though, allowing an antecedent for a silent full noun to be found not just in the preceding discourse context, but also as an activated concept in the community that forms the background of the conversation.

Why do type 2 names select $d$-pronouns and support plural anaphora? There is a double reason for that: first, the presence of the definite determiner and second, the presence of the sortal head noun, which is clearly count, given its overt version.

Type 2 names differ syntactically from close appositions (Jackendoff 1984).

(69) the poet Goethe

Unlike in type 2 names, in close appositions the head noun is obligatory. Moreover, there are constraints on the head noun of close appositions not shared by type 2 names. For example, with

\footnotetext{
${ }^{36}$ There are some yet-to-be-explained differences between the constructions with an overt sortal and an unpronounced sortal. For example, the plural is possible in the former, but not the latter.

(i) die Tempel Horaiji und Toji 'the temples Horaiji and Toji'

${ }^{37}$ French uses close appositions instead: le diamant Hope, l'emeraud Rockefeller.
} 
person names, the head noun of a close apposition cannot be a mere sortal - it must describe a professional role (???the person Goethe). This is naturally explained if a type 1 name occurs in a close apposition together with its silent light noun, so that (69) is in fact as follows:

(70) the poet [Goethe PERSON]

It is a plausible general constraint that the head noun of a close apposition must be a more specific sortal than the light noun that is part of the type 1 name. This is the case for nouns describing professional roles as in (70). Why then is the close apposition die Stadt Berlin 'the city of Berlin' fine? It is because Stadt is more specific than PLACE, the light noun that is part of the type 1 name Berlin PLACE.

\section{The Predicativist Theory of Names}

This article has presupposed the standard view about proper names: as referential terms, they stand for the same individual in different circumstances of evaluation, based on a causal-historical chain (for nonproductive names) and a conventional naming schema (for productive names). The mass status of German place names and productive names has been attributed to the mass status of the light nouns that make up a silent component of such names. There is an alternative to the semantics of names that has been discussed in the recent philosophical literature, namely, the predicativist theory (Matushansky 2008, Fara 2011, 2015). On this theory, names, when forming referential terms, act as part of a definite description with an unpronounced definite determiner, referring to the contextually unique object bearing the property expressed by the name (being called " $\mathrm{N}$ " or standing in a suitable contextually given naming relation to " $\mathrm{N}$ "). This theory appears to offer a simpler account of the mass status of place names in German. German place names would be based on common nouns that would themselves be mass rather than count, instead of being attributed to the mass status of the silent light noun that forms part of the name. This view faces several problems, though.

First, predicativism faces a general issue of linguistic plausibility, which has been elaborated in particular by Hinzen (2015) and Jeshion (2017).

Second, it is not clear how predicativism would explain the mass status of productive names. In fact, it is not clear how the predicativist view applies to productive names in the first place.

Third, predicativism would have a hard time explaining why place names, if they are just common nouns, should classify as mass. Cumulativity and divisiveness, commonly considered defining characteristics of mass nouns in extensional mereological theories (Pelletier and Schubert 1989, 2003), certainly do not hold for place names: a neighborhood of Berlin is not called Berlin, and the Maryland (USA) town of Berlin and the German city are two Berlins; they don't form a single plurality called Berlin. In fact, when names are used as common nouns (derivatively), they clearly are treated as count rather than mass (the two Naples, a second Naples). The problem does not arise on the present view, which traces the mass status of place names to the mass status of the silent noun PLACE rather than the name with its denotation by itself.

Fourth, there are linguistic differences between common nouns and names when used as predicates of small clause complements of verbs of calling. Matushansky (2008) takes it to be 
syntactic evidence for the predicativist theory that (71a) is syntactically parallel to the small clause construction in (71b).

(71) a. Mary called John Bill.

b. Mary called John a fool.

(71a) appears to require the name Bill to make the same sort of semantic contribution as an ordinary predicate such as a fool in the small clause in (71b) - namely, attributing a property of the sort "being called Bill" (or "standing in a suitable contextually given naming relation R to the name Bill") (Matushansky 2008). Despite their similarities, however, (71a) and (71b) are not entirely on a par. Both (71a) and (71b) describe acts of attribution, but the acts are different in type, involving different conditions of satisfaction and different roles for the small clause predicates. These differences manifest themselves syntactically in German, namely, in the choice of different proforms for the small clause predicates. In German, predicational nennen 'to call' as in (71a) goes along with the proforms was 'what' and das 'that' for the small clause predicate, as seen in (72a-b), whereas appellative nennen as in (71b) goes along with the proforms wie 'how' and so 'so', as seen in (73a-b).

(72) a. Anna nannte ihn einen Esel. Maria nannte ihn das / *so auch.

'Anna called him a donkey. Maria called him that too.'

b. Was / *Wie hat Maria ihn genannt? Sie nannte ihn einen Esel.

'What / How did Maria call him? She called him a donkey.'

(73) a. Er nannte sie Susi. Er hätte sie nicht so / *das nennen sollen. he called her Susi he had her not so / that call should 'He called her Susi. He should not have called her so / that.'

b. Wie / *Was hat er sie genannt? Er nannte sie Susi. how / what has he her called he called her Susi 'How / What did he call her? He called her Susi.'

Wie and how are also the proforms used to replace predicational quotations, in (74a-b).

(74) a. Er sprach Küßchen so aus.

he pronounced Küßchen so

'He pronounced Küßchen that way.'

b. Wie sprach er Küßchen aus?

how pronounced he Küßchen

'How did he pronounce Küßchen?'

This indicates that names as small clause predicates with verbs of calling do not contribute a property in the way ordinary small clause predicates do. They may better be considered pure quotations, but now in a predicative function. ${ }^{38}$ The semantic parallelism between (71a) and (71b)

\footnotetext{
${ }^{38}$ The predicativist theory is also motivated by "common noun" occurrences of names as in several Marys or every Kennedy. But see Jeshion 2017 for an account of common noun uses of proper names in terms of meaning shift within the causal theory of names.
} 
then consists in that the act described by the verb of calling is one of attribution of a name (expression type) in (71a) and of a property in (71b). The satisfaction conditions of the former consist in John's having the name, those of the latter in John's having the property. Predicative occurrences of names do not require a property denotation for names, but can be treated as pure quotations. Note that pure quotations can also occur after the preposition as, which is reserved for predicational uses of expressions. ${ }^{39}$

(75) a. John treats Bill as a brother.

b. John pronounced Küßchen as cousin.

Predicative uses of names with verbs of calling thus motivate a more general account of predicative quotation rather than a treatment of names as common nouns.

\section{Conclusion}

This article has argued that the light nouns that are part of light quantifiers in English, German, and other languages are also part of certain types of proper names (namely, type 1 names), which in German include names for persons, places, and houses, as well as productive names. Light nouns display a countability distinction, with THING, PLACE, and TIME siding with mass (noncount) nouns and PERSON and HOUSE with count nouns. This distinction between the two sorts of light nouns explains puzzling differences in behavior among type 1 names regarding the selection of relative pronouns and the ability to support plural anaphora.

Light nouns are not generally sortals, that is, nouns that convey the identity conditions on types of entities. In particular, THING and PLACE comprise particular sortal concepts (material object, artifact, number, expression type, city, country, continent) and thus only have the status of "dummy sortals." Type 1 names are distinguished from type 2 names, which do not involve a light noun, but contain a specific silent or overt full sortal noun in a different syntactic structure.

What does the presence of light nouns in names mean for the semantics of names? One conclusion that can be drawn from the discussion of the role of light nouns in type 1 names is this. Since light nouns in type 1 names are not generally sortals, giving the identity conditions on the object the name stands for, they underspecify the type of entity being referred to and thus are not suited for the role of sortals that some philosophers have taken to be part of the meaning of names (Geach 1957, Dummett 1973). They contrast in that respect with the sortal nouns that

\footnotetext{
predicate.

(i) Er bezeichnete sie als klug. he called her as intelligent 'He called her intelligent.'

(ii) a. Sie nannte ihn einen Esel. 'She called him a donkey.'

b. Sie nannte ihn Johnny.

'She called him Johnny.'

c. ??Er nannte sie klug. 'He called her intelligent.'
}

${ }^{39}$ Call itself may have to be translated into German by a verb taking an as-phrase, namely, with an adjectival

Nennen 'call' only allows NPs and names, not adjectives, as small clause predicates. 
are part of type 2 names. The function of light nouns in type 1 names is thus somewhat different. Note that the view of names that has become standard in philosophy of language generally does not make use of sortals; it simply says that names refer in virtue of a causal-historical chain involving previous uses of the name or else a referent-fixing schema that goes along with a productive process of name formation.

\section{References}

Borer, Hagit. 2005. Structuring sense. Vol. I, In name only. Oxford: Oxford University Press.

Brandt, Patrick, and Eric Fuß. 2017. A corpus-based analysis of pronoun choice in German relative clauses. Belgian Journal of Linguistics 31:195-218.

Brandt, Patrick, and Eric Fuß. 2019. Relativpronomenselektion und grammatische Variation: Was vs. das in attributiven Relativsätzen. In Grammatik im Korpus, ed. by Eric Fuß, Marek Konopka, and Angelika Wöllstein, 91-209. Tübingen: Narr.

Collins, Chris. 2007. Home sweet home. In NYU working papers in linguistics 1, ed. by Lisa Levinson and Oana Savescu-Ciucivara, 1-34. New York: New York University, Department of Linguistics.

Dummett, Michael. 1973. Frege: Philosophy of language. Cambridge, MA: Harvard University Press.

Fara Graff, Delia. 2011. Don't call me stupid. Analysis 71:492-501.

Fara Graff, Delia. 2015. Literal uses of proper names. In On reference, ed. by Andrea Bianchi, 251-279. Oxford: Oxford University Press.

Frege, Gottlob. 1884. The foundations of arithmetic, trans. by John L. Austin. Evanston, IL: Northwestern University Press (1978).

Geach, Peter. 1957. Mental acts. New York: Routledge.

Griffith, Nicholas. 1977. Relative identity. New York: Oxford University Press.

Hinzen, Wolfram. 2016. Linguistic evidence against predicativism. Philosophy Compass 11:591-608.

Hofweber, Thomas. 2005. Number determiners, numbers, and arithmetics. Philosophical Review 114: $179-225$.

Jackendoff, Ray. 1984. On the phrase the phrase 'the phrase'. Natural Language and Linguistic Theory 2: 25-37.

Jeshion, Robin. 2017. 'The' problem for the-predicativism. Philosophical Review 126:219-240.

Kayne, Richard S. 2005. Movement and silence. New York: Oxford University Press.

Kayne, Richard S. 2010. Comparisons and contrasts. New York: Oxford University Press.

Kishimoto, Hideki. 2000. Indefinite pronouns and overt N-raising. Linguistic Inquiry 31:557-566.

Kulkarni, Ritwik, Alessandro Treves, and Susan Rothstein. 2020. Can mass noun syntax be derived from semantics? In Mass and count in linguistics, philosophy, and cognitive science, ed. by Friederike Moltmann, 83-102. Amsterdam: John Benjamins.

Larson, Richard, and Franc Marušič. 2004. On indefinite pronoun structures with APs: Reply to Kishimoto. Linguistic Inquiry 35:268-287.

Linnebo, Øystein. 2017. Plural quantification. In The Stanford encyclopedia of philosophy (Summer 2017 edition), ed. by Edward N. Zalta. https://plato.stanford.edu/archives/sum2017/entries/plural-quant/.

Longobardi, Giuseppe. 1994. Proper names and the theory of N-movement in syntax and Logical Form. Linguistic Inquiry 25:609-665.

Matushansky, Ora. 2008. On the linguistic complexity of proper names. Linguistics and Philosophy 21: $573-627$.

Moltmann, Friederike. 1997. Parts and wholes in semantics. New York: Oxford University Press.

Moltmann, Friederike. 2003. Nominalizing quantifiers. Journal of Philosophical Logic 32:445-481.

Moltmann, Friederike. 2013a. Abstract objects and the semantics of natural language. Oxford: Oxford University Press. 
Moltmann, Friederike. 2013b. Reference to numbers in natural language. Philosophical Studies 162:499-534. Moltmann, Friederike. 2017. Number words as number names. Linguistics and Philosophy 40:331-345. Moltmann, Friederike. 2021. Events and countability. Ms., Ca' Foscari, Venice.

Noonan, Máire. 2017. Dutch and German R-pronouns and P-stranding: R you sure it's P-stranding? In The structure of words at the interfaces, ed. by Heather Newell, Máire Noonan, Glyne Piggott, and Lisa Travis, 209-239. Oxford: Oxford University Press.

Pelletier, Francis Jeffry, and Lenhart K. Schubert. 1989. Mass expressions. In Handbook of philosophical logic, ed. by Dov Gabbay and Franz Guenthner, 327-406. Dordrecht: Kluwer.

Pelletier, Francis Jeffry, and Lenhart K. Schubert. 2003. Mass expressions. In Handbook of philosophical logic, 2nd ed., ed. by Franz Guenthner and Dov Gabbay, 249-336. Dordrecht: Kluwer.

Postal, Paul. 1966. On so-called 'pronouns' in English. In Seventh Annual Roundtable Meeting on Linguistics and Language Studies, ed. by Francis P. Dineen, 177-206. Washington, DC: Georgetown University Press. Reprinted in Modern studies in English, ed. by David A. Reibel and Sanford A. Schane, 204-222. Englewood Cliffs, NJ: Prentice-Hall (1969).

Rayo, Augustin, and Gabriel Uzquiano, eds. 2007. Absolute generality. Oxford: Oxford University Press. Rosefeldt, Tobias. 2008. 'That'-clauses and non-nominal quantification. Philosophical Studies 137:301-333. Rothstein, Susan. 2017. Semantics for counting and measuring. Cambridge: Cambridge University Press. Simons, Peter. 1987. Parts: A study in ontology. Oxford: Oxford University Press.

Strawson, Peter. 1959. Individuals: An essay in descriptive metaphysics. London: Methuen.

Terzi, Arhonto. 2010a. On locative prepositions and place. In Mapping spatial Ps: The cartography of syntactic structure, vol. 6, ed. by Guglielmo Cinque and Luigi Rizzi, 196-224. Oxford: Oxford University Press.

Terzi, Arhonto. 2010b. On null spatial Ps and their arguments. Catalan Journal of Linguistics 9:167-187.

Friederike Moltmann

CNRS-IHPST, Paris and Ca' Foscari, Venice

fmoltmann@univ-paris1.fr 